\title{
Šahrām Zāre‘, Moḥammad Taqī ‘Ațāyī, Ebrāhīm Qezelbāš. Naqš barjasteh sāsānī dar mūzeh Yāsūj / A Sassanian Relief in Yāsuj Museum
}

\section{Rémy Boucharlat}

\section{(2) OpenEdition}

1 Journals

\section{Édition électronique}

URL : http://journals.openedition.org/abstractairanica/42353

DOI : 10.4000/abstractairanica.42353

ISSN : 1961-960X

Éditeur :

CNRS (UMR 7528 Mondes iraniens et indiens), Éditions de l'IFRI

Référence électronique

Rémy Boucharlat, "Šahrām Zāre', Moḥammad Taqī 'Ațāyī, Ebrāhīm Qezelbāš. Naqš barjasteh sāsānī dar mūzeh Yāsūj / A Sassanian Relief in Yāsuj Museum », Abstracta Iranica [En ligne], Volume 34-35-36 | 2017, document 61, mis en ligne le 30 juillet 2017, consulté le 05 octobre 2020. URL : http:// journals.openedition.org/abstractairanica/42353; DOI : https://doi.org/10.4000/abstractairanica. 42353

Ce document a été généré automatiquement le 5 octobre 2020.

Tous droits réservés 


\title{
Šahrām Zāre‘, Moḥammad Taqī 'Ațāyī, Ebrāhīm Qezelbāš. Naq̌̌ barjasteh sāsānī dar mūzeh Yāsūj / A Sassanian Relief in Yāsuj Museum
}

\author{
Rémy Boucharlat
}

\section{RÉFÉRENCE}

Šahrām Zāre‘, Moḥammad Taqī ‘Ațāyī, Ebrāhīm Qezelbāš. « Naqš barjasteh sāsānī dar mūzeh Yāsūj / A Sassanian Relief in Yāsuj Museum ». Bāstānpazhūhi, vol. 6, Nos. 12-13, 2013, p. 130-136.

Note sur une plaque fragmentaire en pierre, large de $31.5 \mathrm{~cm}$, épaisse de $5-7 \mathrm{~cm}$ conservée au musée de Yāsūj, où elle est entrée dans les années 1980. C'est une sorte d'orthostate portant sur une face la représentation d'un buste d'un personnage princier levant un bras. Le vêtement et les rubans flottant autour de l'ample chevelure sous un calot surmonté d'une boule à flammèches sont caractéristiques de l'époque sassanide, plus précisément du début de celle-ci, notent les AA. avec raison. Le musée ne possède pas d'indication sur l'origine de cette découverte fortuite qui ne peut être qu'une construction importante dans une région où les témoins de cette époque sont rares. 


\section{AUTEURS}

\section{RÉMY BOUCHARLAT}

UMR 5133 CNRS-Université de Lyon 